\title{
Anti-inflammatory properties of Dirinaria consimilis extracts in albino rats
}

Vinay Bharadwaj Tatipamula ${ }^{1 *}$, Girija Sastry Vedula ${ }^{2}$

*Corresponding author:

${ }^{1}$ Vinay Bharadwaj Tatipamula, Research Scholar, Pharmaceutical Chemistry Department, University College of Pharmaceutical Sciences, Andhra University, Visakhapatnam - 530 003, Andhra Pradesh, India.

Email: vinaybharadwajt@gmail.com ORCID

\begin{tabular}{l}
\hline${ }^{2}$ Dr. Girija Sastry Vedula, Professor, \\
Chemistry Department, University College of \\
Pharmaceutical Sciences, Andhra University, \\
Visakhapatnam - 530 003, Andhra Pradesh, India. ORCID \\
Information about the article:
\end{tabular}

Received: April, 10, 2018

Accepted: June 28, 2018

Published online: July 12, 2018

\section{Cite this article:}

Tatipamula VB, Vedula GS. Anti-inflammatory properties of Dirinaria consimilis extracts in albino rats. Journal of Biomedical Sciences. 2017;4(1):38.

\section{Publisher}

Nepal Health Research and Welfare Society, Jorpati, Kathmandu, Nepal

eISSN 2382-5545

(C) The Author(s). 2018

Content licensing: $\underline{\text { CC BY } 4.0}$

\section{ABSTRACT \\ Background}

Earlier, the lichens are used in traditional medicines by different cultures across the world. As the Dirinaria genus has been shown to be biologically active against inflammation in folklore, we assessed the in vitro and in vivo anti-inflammatory profile of Dirinaria consimilis.

\section{Material and methods}

Initially, the hydroalcoholic extract of lichen, $D$. consimilis (Dc-HE) was prepared and re-extracted with $n$-hexane, chloroform, ethyl acetate, acetone and methanol. The resultant extracts were evaluated for their in vitro (protein denaturation method), acute toxicity and in vivo (formalininduced rat paw oedema assay) anti-inflammatory studies.

\section{Results}

Among all the tested extracts, the acetone and chloroform extract of $D$. consimilis depicted prominent antiinflammatory activity in both the bioassays. The acetone extract inhibited protein denaturation with $\mathrm{IC}_{50}$ value of about $468 \mu \mathrm{g} / \mathrm{mL}$ while the standard (Indomethacin) with $120 \mu \mathrm{g} / \mathrm{mL}$. Moreover, the Dc-HE was screened for acute toxicity studies in male albino rats up to $2000 \mathrm{mg} / \mathrm{Kg}$ b.w dosage. The in vivo anti-inflammatory analysis of acetone extract $(200 \mathrm{mg} / \mathrm{mL})$ showed potent reduction of rat paw oedema nearer to that of the standard, whereas chloroform extract depicted moderate depletion and the other extracts revealed mild inhibitory profile against inflammation.

\section{Conclusion}

This study reveals that the lichen, $D$. consimilis might be a good source of anti-inflammatory agents.

\section{Keywords}

acute toxicity, Dirinaria consimilis (Stirton) D.D. Awasthi, paw oedema, protein denaturation method 


\section{Introduction}

Inflammation is a usual stimuli to injury and includes the response of the immune system in neutralizing the invading microorganisms, repair of the damaged tissues thereby promoting wound healing. [1] Inflammation process though a self-limiting process, it can become chronic and can further lead to several other serious inflammatory diseases. $[2,3]$ The chronic inflammations may lead to various diseases such as cancer [4], atherosclerosis [5], Alzheimer's [6] and rheumatoid arthritis. [7] Historically, Willow bark extracts were used to treat the fever, inflammation and pain, thereafter the non-steroidal anti-inflammatory drugs (NSAIDs) which include organic acids and non-acidic compounds and coxibs (celecoxib, rofecoxib, etc) were drugs of choice to treat inflammation. [7, 8] In contrast, these synthetic drugs were noticed to have adverse effects on cardiac, gastrointestinal, renal, and vascular functions. [8] Therefore, keeping in mind of the aforementioned drawbacks, the evolution of novel anti-inflammatory agents having lesser adverse effects are highly desirable. In this context, the screening of anti-inflammatory activity of natural product extracts (or) natural product like is an upcoming topic of research owing to lesser side effects. [9, 10]

With this in mind, our attention was drawn towards "Lichens - mutualistic existence of algae and fungi”. Lichen and their secondary metabolites exert a diverse range of pharmacological actions including analgesic, antibiotic, anti-inflammatory, antimycotic, antipyretic, antiviral and cytotoxic effects. [11] Dirinaria consimilis (Stirton) D.D. Awasthi is a foliose lichen belongs to the Dirinaria genus which possesses anticaries, antioxidant, antimicrobial, cytotoxic and larvicidal activities. [12-15] However, there are no pharmacological study reports revealing antiinflammatory potentiality of $D$. consimilis and also keeping in mind of the aforementioned the biological profile of Dirinaria genus and the drawbacks of anti-inflammatory therapeutics, we anticipated Dirinaria consimilis might be active good source for anti-inflammatory activity.

\section{Material and methods}

The present study was undertaken in the Pharmaceutical Chemistry Department, AU College of Pharmaceutical Sciences, Andhra University, Visakhapatnam, India, during the period of 2016-2017.

\section{Collection}

The specimens of mangrove lichen, Dirinaria consimilis (Stirton) D. D. Awasthi was collected on the bark of mangrove plant, Excoecaria agallocha from Vainateya Island, Godavari estuary, Andhra Pradesh, India $\left(16^{\circ} 44^{\prime} 48^{\prime \prime} \mathrm{N}\right.$ and $81^{\circ} 98^{\prime} 19^{\prime \prime} \mathrm{E}$ with $0 \mathrm{~m}$ elevation) in February, 2015. This species were authenticated by Dr. D. K. Upreti, CSIR-National Botanical Research Institute (NBRI), Lucknow and deposited at Lichen herbarium,
CSIR-NBRI, Lucknow, India with accession numbers 15027173.

\section{Extraction}

The lichen specimens were gently collected from the barks of mangrove plant and shade dried. The dried lichen materials $(150 \mathrm{~g})$ were powdered, suspended in ethanolwater (1:1) for a week and evaporated under reduced pressure to obtain hydroalcoholic extracts from $D$. consimilis (Dc-HA, $10.91 \mathrm{~g}$ ). The Dc-HA were re-extracted with solvents of increasing polarity, concentrated to obtain dry extracts of acetone for three times, dried over anhydrous sodium sulphate and concentrated to obtain dry of $D$. consimilis i.e., $n$-hexane (DH, $500 \mathrm{mg}$ ), chloroform (DC, $540 \mathrm{mg}$ ), ethyl acetate (DE, $602 \mathrm{mg}$ ), acetone (DA, $444 \mathrm{mg}$ ) and methanol (DM, $780 \mathrm{mg}$ ), which were preserved at $4{ }^{\circ} \mathrm{C}$ earlier to use.

\section{In vitro anti-inflammatory assay}

Protein denaturation method [16] was employed for the evaluation of in vitro anti-inflammatory activity for $D$. consimilis extracts in three sets and the Mean \pm SD values are reported. Bovine serum albumin protein was used in this study. Study Design - The protein was solubilized to $1 \%$ concentration using sodium phosphate buffer $(50 \mathrm{mM}, \mathrm{pH}$ 6.4). To $0.2 \mathrm{~mL}$ of prepared protein, $0.1 \mathrm{~mL}$ of extract dissolved in DMSO (Sample size - 0.1, 0.2, 0.4, 0.6, 0.8 and $1 \mathrm{mg} / \mathrm{mL}$ for sample) was added and final volume adjusted to $5 \mathrm{~mL}$ with buffer. Then the sample tubes are incubated at $37^{\circ} \mathrm{C}$ for $20 \mathrm{~min}$. Exclusion criteria - Thereafter, the tubes are heated in steam bath at $95^{\circ} \mathrm{C}$ for 20 min and then cooled to room temperature. Finally, the turbidity in the cooled tubes are measured at $660 \mathrm{~nm}$ by UV-Visible Spectrophotometer (Model SL 210, Elico India Ltd.). The percentage inhibition of serum albumin protein denaturation was determined as follows and $\mathrm{IC}_{50}$ values were calculated by plotting concentration vs percentage inhibition.

Percentage inhibition $=[(\mathrm{C}-\mathrm{S}) / \mathrm{C}] \times 100$

where $\mathrm{C}$ is absorbance of Control

$\mathrm{S}$ is absorbance of Sample

\section{Animals}

Healthy albino rats of both sex weighing 180-200 g, matured between 2-3 months are fed with water (ad libitum) and standard pellet diet are used for the contemporary study. Selected animals were adapted to the standard conditions for at least seven days before the exploration. The experimental protocols are maintained as per the Institutional Animals Ethical Committee and Control and Supervision of Experiments on Animals (CPCSEA) guidelines for experimental clearance (516/PO/c/01/CPCSEA).

\section{Acute Toxicity studies}

The acute toxicity studies of the Dc-HA were performed by Oral Acute Toxic Class method [17] and as per OECD 
Table 1: In vitro anti-inflammatory effect of $D$. consimilis extracts against serum albumin protein $(n=3)$

Sample

DH

DC

DE

DA

DM

Indo

Percentage inhibition at different concentration (\%)

\begin{tabular}{cc}
$\mathbf{0 . 2} \mathbf{~ m g} / \mathbf{m L}$ & $\mathbf{0 . 4} \mathbf{~ m g} / \mathbf{m L}$ \\
$4.10 \pm 0.09$ & $7.66 \pm 0.65$ \\
$17.45 \pm 2.96$ & $25.95 \pm 0.82$ \\
$2.72 \pm 0.90$ & $4.36 \pm 0.87$ \\
$34.96 \pm 1.16$ & $45.64 \pm 1.11$ \\
$1.36 \pm 0.45$ & $2.18 \pm 0.43$ \\
$62.57 \pm 2.21$ & $70.46 \pm 2.27$ \\
\hline
\end{tabular}

$\mathbf{0 . 6} \mathbf{~ m g} / \mathbf{m L}$
$9.29 \pm 0.45$
$41.01 \pm 1.62$
$8.47 \pm 1.18$
$58.44 \pm 2.09$
$3.82 \pm 0.89$
$78.70 \pm 1.97$

$0.8 \mathrm{mg} / \mathrm{mL}$

$1 \mathrm{mg} / \mathrm{mL}$

$0.1 \mathrm{mg} / \mathrm{mL}$

$3.15 \pm 0.69$

$13.40 \pm 1.15$

$0.82 \pm 0.018$

$20.22 \pm 0.09$

$0.27 \pm 0.47$

$62.57 \pm 2.21$

$70.46 \pm 2.27$

guidelines for their $\mathrm{LD}_{50}$ in male rats. In this evaluation, two groups of male albino rats $(n=6)$ administered intraperitoneally with at 1000 and $2000 \mathrm{mg} / \mathrm{Kg}$ body weight (b.w) and all the animals were retained under examination for $24 \mathrm{~h}$. During this duration biological and physiological changes like aggressiveness, respiratory movements, mortality, skin changes etc., were noted.

\section{In vivo assay}

The in vivo anti-inflammatory activity was performed by formalin-induced hind rat paw oedema assay by using plethysmographic measurement of rat paw oedema caused by sub-plantar administration of $1 \% \mathrm{w} / \mathrm{v}$ formalin in the hind rat paw $[18,19]$. The healthy albino rats of both sex were categorized into batches containing six albino rats $(n=6)$ each. First batch served as control (administered only with 0.5\% carboxymethyl cellulose), second for standard drug, indomethacin $(100 \mathrm{mg} / \mathrm{Kg}$ b.w) and the remaining batches served for test extracts. In order to attain accurate measurement of the paw oedema, spotting was done at just behind the tibiotorsal junction on both the hind rat paws, so that to ensure constant paw volume the paw was inserted in mercury column up to fixed mark. Inclusion criteria - All the test samples $(100,200 \mathrm{mg} / \mathrm{Kg}$ b.w) were deliquesced in $0.5 \%$ carboxymethyl cellulose and administered intraperitoneally. Immediately $30 \mathrm{~min}$ after sample dosage, $0.1 \mathrm{~mL}$ of $1 \% \mathrm{w} / \mathrm{v}$ formalin was administered in the plantar region of the rat left paw. The non-inflammated right paw is assisted as a reference standard. Exclusion criteria - The rat paw volume of all tested animals were measured at 2, 4 and $6 \mathrm{~h}$ after the sample dosage. Hence, the percentage of variation in rat paw oedema was measured and compared with that of the standard tested drugs at respective intervals of time i.e., 2, 4 and 6 h. The percentage reduction of rat paw oedema at mentioned intervals of time in the treated rats were measured by using below equation.

Percentage inhibition $=(C-\mathrm{T}) / \mathrm{C} \times 100$

$\mathrm{C}=$ volume of paw rat oedema in control animals

$\mathrm{T}=$ volume of paw rat oedema in treated animals

\section{Statistical analysis}

The results are mentioned as Mean \pm SEM values of six independent experiments. Statistical significance $(\mathrm{AP}<0.05)$ value between the batches was measured by one-way analysis of variance (ANOVA) followed by Dunnett's test.

\section{Results}

\section{In vitro anti-inflammatory studies}

The denaturation of biological proteins causes inflammation. The denaturation pathways can be by acidic (or) alkaline reactions, heat treatment, radiation reactions, etc. Proteins lose their complex tertiary structure because of the externally induced stress under the above mentioned conditions thus leading to denaturation. The in vitro antiinflammatory capability of $D$. consimilis extracts (DH, DC, DE, DA and DM) were initially subjected to protein denaturation method [16] using different concentration (0.1$1 \mathrm{mg} / \mathrm{mL}$ ) for extracts as well as standard (indomethacin) and data is tabulated in Table 1.

The data evident that the DC and DA revealed prominent anti-inflammatory profile, besides, DH, DE and DM depicted moderate anti-inflammatory activity (Table 1). The DA and DC $(1 \mathrm{mg} / \mathrm{mL})$ showed good inhibitory activity against protein denaturation with $80.08 \pm 2.61$ and $71.04 \pm 1.77 \%$, respectively, while standard drug (Indo, 1 $\mathrm{mg} / \mathrm{mL}$ ) with $93.71 \pm 1.29 \%$ (Table 1). Similarly, the percentage inhibition of bovine albumin protein denaturation for $\mathbf{D H}, \mathbf{D E}$ and $\mathbf{D M}$ were noticed to be $21.04 \pm 0.73,23.50 \pm 0.99$ and $14.22 \pm 0.79 \%$, respectively (Table 1). As shown in illustrated in Figure 1, the $\mathrm{IC}_{50}$ values for DC and DA were 0.706 and $0.468 \mathrm{mg} / \mathrm{mL}$, respectively, with respect to standard (Indo, $0.120 \mathrm{mg} / \mathrm{mL}$ ), whereas DH, DE and DM did not show better inhibition of albumin protein up to $1 \mathrm{mg} / \mathrm{mL}$ concentration.

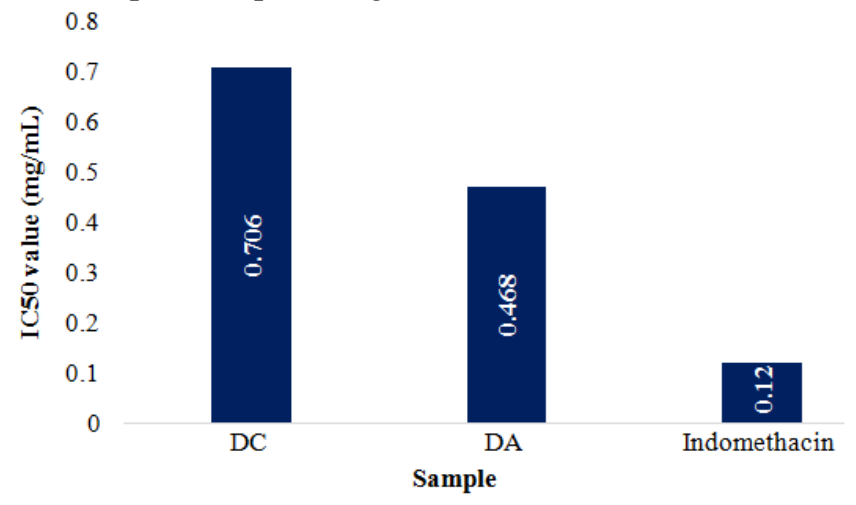

Figure 1: $\mathrm{IC}_{50}$ values of $\mathbf{D C}$ and $\mathbf{D A}$ extracts in protein denaturation method 


\begin{tabular}{|c|c|c|c|c|c|c|c|}
\hline \multirow[b]{2}{*}{ Sample } & \multirow{2}{*}{$\begin{array}{c}\text { Dosage } \\
\text { (mg/Kg) }\end{array}$} & \multicolumn{2}{|c|}{$2 \mathrm{~h}$} & \multicolumn{2}{|c|}{$4 \mathrm{~h}$} & \multicolumn{2}{|c|}{$6 \mathrm{~h}$} \\
\hline & & $\begin{array}{l}\text { Raise in Paw } \\
\text { edema volume }\end{array}$ & $\%$ inhibition $^{\#}$ & $\begin{array}{l}\text { Raise in Paw } \\
\text { edema volume }\end{array}$ & $\%$ inhibition $^{\#}$ & $\begin{array}{l}\text { Raise in Paw } \\
\text { edema volume }\end{array}$ & $\begin{array}{c}\% \\
\text { inhibition }^{\#}\end{array}$ \\
\hline \multirow[t]{2}{*}{ DH } & 100 & - & - & - & - & - & - \\
\hline & 200 & $1.71 \pm 0.11$ & $5.73 \pm 0.56$ & $2.02 \pm 0.08$ & $4.88 \pm 1.00$ & $2.19 \pm 0.06$ & $1.57 \pm 0.27$ \\
\hline \multirow[t]{2}{*}{ DC } & 100 & $1.53 \pm 0.08$ & $15.26 \pm 0.80$ & $1.87 \pm 0.07$ & $12.17 \pm 0.61$ & $2.00 \pm 0.05$ & $10.02 \pm 0.46$ \\
\hline & 200 & $1.34 \pm 0.08$ & $26.09 \pm 0.75$ & $1.29 \pm 0.04$ & $39.14 \pm 1.70$ & $1.71 \pm 0.03$ & $23.16 \pm 1.57$ \\
\hline \multirow[t]{2}{*}{ DE } & 100 & - & - & - & - & - & - \\
\hline & 200 & $1.69 \pm 0.10$ & $6.83 \pm 0.53$ & $1.95 \pm 0.07$ & $8.40 \pm 0.27$ & $2.16 \pm 0.06$ & $3.07 \pm 0.80$ \\
\hline \multirow[t]{2}{*}{ DA } & 100 & $1.26 \pm 0.07$ & $30.30 \pm 0.88$ & $1.41 \pm 0.06$ & $33.83 \pm 1.16$ & $1.51 \pm 0.05$ & $32.09 \pm 0.90$ \\
\hline & 200 & $1.08 \pm 0.08$ & $40.60 \pm 1.21$ & $0.90 \pm 0.05$ & $56.43 \pm 0.75$ & $1.22 \pm 0.003$ & $45.10 \pm 0.82$ \\
\hline \multirow[t]{2}{*}{ DM } & 100 & - & - & - & - & - & - \\
\hline & 200 & $1.80 \pm 0.11$ & $0.56 \pm 0.03$ & $2.10 \pm 0.07$ & $1.10 \pm 0.23$ & $2.22 \pm 0.06$ & $0.52 \pm 0.18$ \\
\hline Indo & 100 & $0.98 \pm 0.06$ & $45.81 \pm 1.00$ & $0.83 \pm 0.03$ & $61.14 \pm 0.70$ & $0.73 \pm 0.02$ & $67.31 \pm 0.21$ \\
\hline
\end{tabular}

\section{Acute toxicity studies}

By following the Oral Acute Toxic Class method, Dc-HA were evaluated for median lethal dose $\left(\mathrm{LD}_{50}\right)$ value in male albino rats using standard protocol. The Dc-HA showed no clinical signs in the albino rats as evidenced by the $\mathrm{LD}_{50}$ value of above $2 \mathrm{~g} / \mathrm{Kg}$ b.w. From the observations, the dosage was deliberated by Smith method and found to be 100 and $200 \mathrm{mg} / \mathrm{Kg}$ b.w.

\section{In vivo assay}

The extracts of Dirinaria consimilis are active against in vitro denaturation of protein, we extended the study to evaluate them for in vivo anti-inflammatory activity by using formalin-induced rat paw oedema assay by plethesmography. $[18,19]$ The results are represented as the percentage reduction of oedema measured to basal paw volume.

Considering the in vitro anti-inflammatory analysis and acute toxicity studies, the extracts at 100 and $200 \mathrm{mg} / \mathrm{Kg}$ b.w were subjected to standard in vivo protocol (formalininduced rat paw oedema assay by plethesmography) of antiinflammatory activity against standard drug (Indo, 100 $\mathrm{mg} / \mathrm{Kg} \mathrm{b.w}$ ). It is evident for the data that the all the extracts depicted dose dependent reduction of paw oedema in formalin-induced rats. The animals administered with lower dose of DA $(100 \mathrm{mg} / \mathrm{Kg} \mathrm{b.w})$ depicted $30.30 \pm 0.88$, $33.83 \pm 1.16$ and $32.09 \pm 0.90 \%$ reduction of their paw oedema at 2, 4 and $6 \mathrm{~h}$, respectively, while more pronounced effect of $40.60 \pm 1.21, \quad 56.43 \pm 0.75$ and $45.10 \pm 0.82 \%$, respectively, depletion of paw oedema was observed in rats treated with higher dose of DA $(200 \mathrm{mg} / \mathrm{Kg}$ b.w), which was almost nearer to that of the standard drug (Indo, $100 \mathrm{mg} / \mathrm{Kg}$ b.w) (Table 2). The DC showed moderate percentage reduction of paw oedema at 2, 4 and 6 $h$, whereas the DH, DE and DM revealed mild anti- inflammatory activity at tested doses during the noted hours (Table 2).

At higher doses of DC (200 mg/Kg b.w) exhibited better depletion of rat paw oedema than the lower doses. The rats treated with DC at $100 \mathrm{mg} / \mathrm{Kg}$ b.w revealed $15.26 \pm 0.80$, $12.17 \pm 0.61$ and $10.02 \pm 0.46 \%$ reduction in their paw oedema at 2, 4 and 6 h respectively, while DC at 200 $\mathrm{mg} / \mathrm{Kg} \quad$ b.w showed $26.09 \pm 0.75, \quad 39.14 \pm 1.70$ and $23.16 \pm 1.57 \%$ at 2, 4 and $6 \mathrm{~h}$, respectively (Table 2). From the outcomes it can be deduce that the acetone and chloroform extracts of Dirinaria consimilis are highly effective in reducing paw oedema in rats as that of the standard drugs.

\section{Discussion}

Inflammation is immensely complex and captivating. It is an elementary way in which the living tissue retaliates to injury, infection or irritation by engendering the cardinal signs i.e., calor, dolor, function laesa, rubor and tumor [1]. Basically inflammation is categorized into two forms acute (rapid stimuli to injury by furnishing plasma proteins and leukocytes to the active site of injury) and chronic inflammation (perpetuated period of inflammation) [5, 6]. Generally, acute inflammation leads to appendicitis, bronchitis, dermatitis, meningitis, sinusitis, sore throat and tonsillitis, while chronic inflammation causes aging, Alzheimer's, asthma, atherosclerosis, cancer, Crohn's disease, hepatitis, peptic ulcer, periodontitis, psoriasis, rheumatoid arthritis, sclerosis, sepsis and tuberculosis diseases [4]. On the other hand, naturally occurring antiinflammatory extracts or metabolites are preferred due to lesser side effects. In this context, lichen extracts and metabolites are chosen due to their strong pharmacological reports against inflammation [11, 12].

In the present study, preliminary screening for antiinflammatory activity was performed with protein denaturation method using bovine serum albumin protein. 
The tested extracts produced mild to significant inhibitory profile towards protein denaturation. Among all the tested extracts, the DA and DC depicted prominent in vitro antiinflammatory activity, which were nearer to that of the standard (indomethacin) (Figure 1). Considering the in vitro anti-inflammatory profile, we have initially screened for acute toxicity studies using male albino rats and found that the $\mathrm{D}$. consimilis was non-toxic up to $2 \mathrm{~g} / \mathrm{Kg}$ b.w. Based on the in vitro assay and oral acute toxic class method, the in vivo anti-inflammatory screening was evaluated in albino rats using formalin induced hind rat paw oedema assay at low and high doses. At both the dosage, the DA and DC showed potent inhibitory profile against rat paw oedema. Moreover, both the bioassays outcomes are almost similar and consistent.

The illustrations of the present experiment propose that the $D$. consimilis extract has prominent anti-inflammatory profile against chronic models like formalin-induced rat hind paw oedema. This in vivo model is not only suitable for screening anti-inflammatory activity but also antiarthritic activity. Hence, the research findings justify that the utilization of $D$. consimilis extracts in traditional medicine assist for the treatment of acute and chronic inflammation, in particularly associated with arthritis. Furthermore, the suppression effect of the extracts of $D$. consimilis may be due to the inhibition of the biosynthesis of prostanoids ( $\mathrm{PGE}_{2}, \mathrm{PGF}_{2 \alpha}, \mathrm{PGD}_{2}, \mathrm{PGI}_{2}$ ), thromboxane $\left(\mathrm{TXA}_{2}\right)$ and Interluekin-8 which are well known COX pathway products or modulation of reactions between mediators and respective receptors or by irreversible blockade of the receptor activity.

\section{Conclusion}

This is a preliminary report of pharmacological profile of lichen, Dirinaria consimilis. The anti-inflammatory activity was assessed by two experimental models. In protein denaturation method (in vitro), the DA depicted prominent protein inhibitory profile with IC $_{50}$ values of $468 \mu \mathrm{g} / \mathrm{mL}$. In formalin induced hind rat paw oedema assay (in vivo), the DA (at both doses) revealed good inhibitory profile against rat paw oedema, demonstrative of both acute and chronic inflammation. Hence, both the bioassays depicted that the lichen, $D$. consimilis has good inhibitory profile against inflammation. Hence, it can be concluded that the $D$. consimilis have an aptitude to reduce rat paw oedema as well as inhibit protein denaturation

\section{Abbreviations}

Acetone extract of Dirinaria consimilis (DA), Chloroform extract of Dirinaria consimilis (DC), Dimethyl sulfoxide (DMO), Ethyl acetate extract of Dirinaria consimilis (DE), Hydroalcoholic extract of Dirinaria consimilis(Dc-HE), Lethal dose (LD), Methanol extract of Dirinaria consimilis (DM), nhexane extract of Dirinaria consimilis (DH),
Organization for Economic Cooperation and Development (OECD), Standard Error of the Mean (SEM)

\section{Acknowledgments}

We thank the Ministry of Earth Sciences (Grant number: A.V (1)/MOES-2/DS/6/2017), India for the financial support.

\section{Authors' contribution}

Both the authors have equally contributed.

\section{Competing interests}

The authors declare no conflicts of interest.

\section{Limitations \& future scope of the study}

The chemical components which are responsible for anti-inflammatory abilities are currently unclear. Therefore, the chemical and biological examination of the extracts of $D$. consimilis are under progress in our research laboratory in order to isolate and identify the bioactive compounds present in this lichen.

\section{Publisher's Note}

NHRWS remains neutral with regard to jurisdictional claims in published maps and institutional affiliations.

The publisher shall not be legally responsible for any types of loss, actions, claims, proceedings, demand or costs or damages whatsoever or howsoever caused arising directly or indirectly in connection with or arising out of the use of this material.

\section{References}

1. Tracey KJ. The inflammatory reflex. Nature 2002; 420(6917):853-859.

DOI: https://doi.org/10.1038/nature01321

2. Chen LZ, Sun WW, Bo L, Wang JQ, Xiu C, Tang WJ, Shi JB, Zhou HP, Liu XH. New arylpyrazoline-coumarins: Synthesis and antiinflammatory activity. European Journal of Medicinal Chemistry 2017; 138:170-181. DOI: https://doi.org/10.1016/j.ejmech.2017.06.044

3. Ferrero-Miliani L, Nielsen O, Andersen PS, Girardin SE. Chronic inflammation: importance of NOD2 and NALP3 in interleukin-1beta generation. Clinical and Experimental Immunology 2006; 147:227-235. DOI: https://doi.org/10.1111/j.13652249.2006.03261.x

4. Libby P. Inflammation in atherosclerosis. Nature 2002; 420(6917):868-874. DOI: https://doi.org/10.1038/nature01323 
5. Kim HY, Kim HV, Jo S, Lee CJ, Choi SY, Kim DJ, Kim Y. EPPS rescues hippocampus-dependent cognitive deficits in APP/PS1 mice by disaggregation of amyloid- $\beta$ oligomers and plaques. Nature Communications 2015; 6:8997. DOI: https://doi.org/10.1038/ncomms9997

6. Rommel C, Camps M, Ji H. PI3K $\delta$ and PI3K $\gamma$ : partners in crime in inflammation in rheumatoid arthritis and beyond?. Nature Reviews Immunology 2007; 7:191-201. DOI: https://doi.org/10.1038/nri2036

7. Velazquez CA, Chen QH, Citro ML, Keefer LK, Knaus EE. Second-generation aspirin and indomethacin prodrugs possessing an $\mathrm{O}(2)$ (acetoxymethyl)-1-(2-carboxypyrrolidin-1-

yl)diazenium-1,2-diolate nitric oxide donor moiety: design, synthesis, biological evaluation, and nitric oxide release studies. Journal of Medicinal Chemistry 2008; 51(6):1954-1961. DOI: https://doi.org/10.1021/jm701450q

8. FitzGerald GA. Coxibs and cardiovascular disease. The New England Journal of Medicine 2004; 351(17):1709-1711.

DOI: https://doi.org/10.1056/NEJMp048288

9. Palkar MB, Singhai AS, Ronad PM, Vishwanathswamy AHM, Boreddy TS, Veerapur VP, Shaikh MS, Rane RA, Karpoormath R. Synthesis, pharmacological screening and in silico studies of new class of Diclofenac analogues as a promising anti-inflammatory agents. Bioorganic \& Medicinal Chemistry 2014; 22(10):2855-2866. DOI: https://doi.org/10.1016/j.bmc.2014.03.043

10. Patil SA, Patil SA, Patil R. Microwave assisted synthesis of chromenes: Biological and chemical importance. Future Medicinal Chemistry 2015; 7(7):893-909.

DOI: https://doi.org/10.4155/fmc.15.38

11. Tatipamula VB, Vedula GS, Rathod BB, Shetty PR, Sastry AVS. Study of Phytochemical Analysis, Total Flavonoid and Phenolic content, Antimicrobial Properties and Chemical Constituents of two Manglicolous Lichens Extracts. Inventi Rapid: Planta Activa 2018; 2018(2):1-6. DOI: http://inventi.in/journal/article/rapid/61/25058/plan ta-activa/h

12. Nanayakkara $C$, Bombuwela $K$, Kathirgamanathar S, Adikaram NKB, Wijesundara DSA, Hariharan GN, Wolseley P, Karunaratne V. Effect of some Lichen extracts from Sri Lanka on Larvae of Aedes aegypti and the fungus Cladosporium cladosporioides. Journal of the National Science Foundation of Sri Lanka 2005; 33(2):147-149. DOI: http://doi.org/10.4038/jnsfsr.v33i2.2345

13. Prashith KTR, Dhanya R, Dhatri R, Sunita CM, Onkarappa R, Vinayaka KS. Radical Scavenging, antimicrobial and insecticidal efficacy of Parmotrema cristiferum and Dirinaria applanata. Science, Technology and Arts Research Journal. 2015; 4(1):95-102. DOI: http://dx.doi.org/10.4314/star.v4i1.16

14. Prashith KTR, Vinayaka KS. In vitro Anticaries activity of some Macrolichens of Karnataka, India. International Journal of Pharma Research and Health Sciences 2016; 4(3):1244-1248. DOI: http://dx.doi.org/10.21276/ijprhs.2016.03.16

15. Ahmed EF, Elkhateeb WA, Taie HAA, Rateb ME, Fayad W. Biological Capacity and chemical composition of secondary metabolites from representative Japanese Lichens. Journal of Applied Pharmaceutical Sciences 2017; 7(01):98103.

DOI: http://dx.doi.org/10.7324/JAPS.2017.70113

16. Mizushima Y, Kobayashi M. Interaction of anti-inflammatory drugs with serum proteins, especially with some biologically active proteins. Journal of Pharmacy and Pharmacology 1968; 20(3):169-73. DOI: https://doi.org/10.1111/j.20427158.1968.tb09718.x

17. Isbrucker RA, Edwards JA, Wolz E, Davidovich A, Bausch J. Safety studies on epigallocatechin gallate (EGCG) preparations. Part 2: dermal, acute and short-term toxicity studies. Food and Chemical Toxicology 2006; 44(5):636-650. DOI: https://doi.org/10.1016/j.fct.2005.11.003

18. Roche AK, Cook M, Wilcox GL, Kajander KC. A nitric oxide synthesis inhibitor (L-NAME) reduces licking behavior and Fos-labeling in the spinal cord of rats during formalin-induced inflammation. Pain 1996; 66(2-3):331-341. DOI: https://doi.org/10.1016/0304-3959(96)03025-4

19. Dharmasiri MG, Jayakody JRAC, Galhena G, Liyanage SSP, Patnasooriya WD. Antiinflammatory and analgesic activities of mature fresh leaves of Vitex negundo. Journal of Ethnopharmacology 2003; 87(2-3):199-206. DOI: https://doi.org/10.1016/S0378-8741(03)00159-4 